\title{
Modern World Needs Laozi's Wisdom about the Substance of Being and Living in Harmony with Nature
}

\author{
Maria Ferancova(Marina Čarnogurská) \\ Institute of Oriental Studies, Slovak Academy of Sciences, Slovak Republic
}

Copyright $(2015$ Horizon Research Publishing All rights reserved.

\begin{abstract}
Although Christianity remains even today the major ideological backbone of our Western civilization with its common belief that the Nature on Earth is only a terrestrial environment given to us by a transcendent God-Creator for our everyday use and living needs, other world civilizations (especially the Chinese, which has managed to define and record its original world-view heritage already 3,000 years ago) offer to us some different explanations and viewpoints. Thus in Chinese philosophical heritage we can learn from Laozi's ontological teaching that the Universe (or Multiverse) was not created by any transcendent God from an absolute vacuum (or "Nothing"), as in ancient Chinese original worldview there never existed any absolute vacuum (or a real "Nothing"). In Laozi's as well as the primeval Chinese interpretations, the Universe has not originated from a singularity set by a transcendent God from within an absolute vacuum, where by his divine intervention he subsequently created its consequential multi-variety, but in accordance with Laozi's ontological theory Universe (or Multiverse) was and is forever because of its basic substrate of yin-yang Energy (De), which is moveable thanks to its bipolar positively-negatively everlastingly polarized medium. Thanks to it, the Universe (or Multiverse) was and will be forever in its interchangeable dialectical movements continually creating by its multidimensional tensions a wonderful variability of its opposites. In our three-dimensional time-space (which is with our whole Cosmos an inner subset of it, too), the "metaphysical" and "physical", "spiritual" and "material" also are in every case only yin-yang (negatively-positively) interchangeable cyclical and transitional states and the reactions, creations and extinctions of its infinitely and eternally never-ending Unity, which can never be a static singularity! In such conditions also our Earth and the Human world (as one of the inner parts of Universe) ought to live in accordance with these natural laws of the basic Energy (De), and everything here is "governed" (according to Laozi's metaphysical interpretation) by its anonymous inner powers, and thus not by any subjective First Mover (or in our sense a God). Therefore, also our Human race is obliged to live and behave in a harmonious coordination with natural principles and regularity, common to this
\end{abstract}

whole anonymous process of transformations in the endless circulation of Universe (or Multiverse).

Keywords Laozi, Fundamental Energy De, Cyclic, Metaphysical - Material Coexistence

\section{A General Preface of Antithetic Western and Chinese Worldview's Roots}

It is a great misfortune that our modern highly consumerist world (strongly influenced by "westernization") has entirely ceased to respect the environment on Earth and still recklessly plunders its Nature, looking on its environment mainly as on a source of energy and raw materials for the production of industrial and material goods. It looks as the Western people are still inspired by the traditional ideological backbone of our civilization in the sense that our terrestrial environment had been given to Humans by God for using it for our every day's consumerist needs. Comparing this conviction with (for over 3000 years lasting) worldview of another civilizations on Earth (mainly Chinese) we can learn that an everlasting Universe (or Multiverse) of being was not created by God, because it is being in itself as an eternal and endlessly changing living organism thanks to its all-permeating anonymous Energy (De) and its yin-yang dialectical Way (Dao), in which "metaphysical" and "material", spiritual and natural (or physical), isn't a subject-object linearity of God's (or some other's) creations, but it is a cyclically eternal, within itself changing complementary interoperable and organically anonymous immanency of its common Unity of one. Thus also our Cosmos as well as the Earth and the human race living here is only an inner subset of it, just at this time existing as its immanent forms of being, and therefore we are forced to accept it and to behave on Earth (as one of its forms) in harmonious synergy with all regularities common to this particular unity of the Universe of being. Function of Mankind in it, arising at the moment of his/her birth, should 
never be embodied only into maximizing personal or common material benefit and economic interests, but into a coordinated effort of its maximally cooperating organism inside this unity. Of course, it also means that people should not focus their minds mainly on consumer care about themselves, while ignoring the real patterns of the natural course of the reality in the world!

In recent centuries our science, thanks to its ever improving research abilities, begins to map out many new details and seek by its own way the most rational analysis of the actual state of being in a variety of fields, and scientists want truly explain and scientifically rightly define all dissimilarities and enigmas of the existence of being. Unfortunately, most scientists are not willing to be influenced in their search for discoveries by any other than just our European or pro-Western ideological views. It is still dominant also in many new scientific explanations, for example about the substance of being or about the life on Earth, in what is still a strong influence of only traditional Christian (or Jewish or Islamic) angles of view in seeking new scientific knowledge. Thus these monotheistic religions influence in advance the only acceptable methodology for achieving "scientific" result which is connected only with a divine creation in a non-bipolar singularity. Thus many Western scientists are unable to think, for example, in ancient Chinese intentions of worldview represented by Laozi's ontological research of the reality, based on his observations that all-abound him in the countryside is permeated and created by an interactive (thanks to its dialectical bipolarity) basic movable substrate of Energy (De), which Energy includes in itself the whole completion of its natural laws that enable its yin-yangly dialectical motion. Thanks to Laozi's scientific insight our physicists, for example, would be able not only to discover in a vacuum the everlasting motion of the substantive Energy of being, which they define as "the Strings theory", but also to understand why and for which basic causes of these "strings" are forever in motion and why they don't need for their movement any First Mover. (In my opinion it could be a reasonable cause to consider Laozi's theory of being as scientifically helpful, couldn't be?)

However, we are still influenced by our Greco-Roman-European as well as Judeo-Christian-(Islamic) worldview's traditions which began to form in our pre-history, probably from initially nomadic roots of conquerors roaming and occupying still new large territories and behaving as "herds under the leadership of their very strong leader". By such a way of evolution, Westerners hardly could have learned to be helpful and conductive parts of Nature on Earth, because they created (thanks to migratory and later conquerors' lifestyles) their subjective assumptions about the way of life in discord with the regularities of Nature and, at the same time, they have developed for themselves a faith based on their false presumption an abstraction of an existence of a supernatural Man-(Leader) for whom they invented an instantiative transcendental God.1

Although the West in its history came into impact with many other world cultures and civilizations, it did not accept any other type of belief and Christianity remains the backbone of its worldview till now. At the same time, true to their origins in Greco-Roman (and later Saxon-Germanic, etc.) military conquerors' lifestyle, Westerners have often liked to behave throughout their history towards all the other human cultures in the World very aggressively, and after conquests of their territories and ideological subjugation, they destroyed their original culture, and by any means influenced them to accept Western life-style and as quickly as it was possible colonized them acquiring with it a right to force on them our Western world-view and beliefs as well as only our Western ethical norms of human behaviors. In short: - Westerners have forced all these subjugated nations to change from "pagans" to only acceptable "civilized" Christians (or in some parts of World to only acceptable "civilized" Muslims), completely ignoring in this process the original cultural and ideological identities of those original "pagans".

From all other world civilizations that existed on Earth and had completely different outlook on life than Western conquerors, in such circumstances survived to the modern age and defended against the Western ideological pressure only the civilizations of the Far East, especially Chinese. Actually only they continued through the ages in their own governmental and ideological sovereignty up to the present time. And thus today, in the most important ideological dispute about the basic Truth of life there are on the same level of importance (with their totally contradictory ideological attitudes, philosophical opinions and ethical systems of moral principles) in fact only these two world civilizations: Western and Far Eastern (whose main representative was and predominantly still is China!)

\section{Basic Metaphysical Roots of the Primeval Chinese Worldview, Philosophically Expressed by Laozi's Theory of Being as a Way (Dao) of a Universal Energy (De)}

From the earliest times in agrarian China (which, from the $3^{\text {rd }}$ millennium B.C. to the present time geopolitically still existed at one and the same territory) the primary economic environment has always been an agricultural countryside. In such environments people have been forced to habituate and live in a perfect coexistence with Nature and to be familiar with the natural laws of its reality. Thus their consciousness

1 Of course, it wasn't a simple process of transformation, and in western history it was initiated by many different processes of various religious forms and aspects of many, first of all, polytheistic pantheons, but in the year 325 , during the reins of Constantine the Great (324-337) the first ecumenical council promulgated the highly monotheistic Christianity to be the official religion of Roman Empire and from that time it became the chief ideological backbone of our Western civilization. 
did not perceive Nature as an alienated object of exploitation, but since the oldest times they accepted it as a vital environment of a vivid process of cyclically natural changes (of reciprocally very different qualities) and already in the pre-historical times their shamans began to explain it by yin-yang dialectical graphics of two opposite waves folded one into the other, as well as by its eight trigrams, annotated by Chinese shamans in their oldest oracular guide known as the Book of Changes (Yi jing). Such metaphysical illustration of the fundamental substance of being began to be expressed, from the end of the $6^{\text {th }}$ century $\mathrm{BC}$, also by highly sophisticated philosophical reflections, firstly in the text of an Old Master (Laozi), known to us as Dao De jing, and later by many philosophical schools and personalities in the time of so-called period of "Hundred schools" $\left(3^{\text {rd }}\right.$ cent. BC), as well as later by two most important ideological worldview's alternations: Taoism and Confucianism 2 .

From those times majority of ancient Chinese thinkers (thanks to Laozi's philosophical explanation) were accustomed to define the original substance of being as an antithetically polarized energy (though they later started to use to express it unfortunately only by the term 氣 qi!) of an infinite one, which is yin-yangly dialectically ever-changing in itself and through innumerable cycles of changes is emerging through its synergy in continuously another new forms and qualities of being. However, Laozi was the only one, who defined it by his original metaphysical terms as a process of changes of a basic Energy (De 德) by its Way (Dao 道), what is metaphysically de facto an Emptiness full of movement. As he said: "Between Heaven and Earth it is like a blower, empty, and therefore frictionless, full of movement and therefore acting from itself more and more. Any words are dispensable! (For us) nothing than to cling to the Middle! 天地之間其猶㯻篇乎?虛而不屈, 動而愈出. 多言數窮,不如守中“3 All these Laozi's words are still valid and highly factual event now, because such metaphysical reality exists regardless of time and space in every place on Earth and in Cosmos which is a just existing inner subset of an everlasting and endless Universe (or

2 In contrary to Laozi, Confucius is only a great Teacher of Ethics, and he never has been a metaphysical thinker. He accepted (after visiting Laozi in Luoyang), the metaphysical term Dao (The Way of being), but he was not able to understand what is that Laozi's metaphysical term "De"! However, he understood that De is something very important in the Universe of being which has the power to harmonize everything there, and thus he implicated it into his ethical theory as the greatest Virtue. Later, when Confucianism was promoted in China to be a state ideology, majority of Chinese began to accept it only as the Confucian greatest Virtue and Laozi's Dao De jing they interpreted from that time only as the text about Dao and glorified The Way of Dao into a "deus et machine" movable from itself. They forgot or ignored that in Laozi's explanation it is only a Way (Dao) of De and that the De (as the basic Energy of Universe/or Multiverse) is the most important part in it. Only thanks to my deep analysis of many copies of Laozi's texts of Daodejing I found this to be forgotten even in China as its real and the most important ontological content. After the 3nd century, Taoist philosophy lost in China conditions for its further development and it continued there only inside the Taoist religion, which is something quite different from Laozi's philosophical thinking. Taoists then became only priests of a common folk religion and not the brilliant Chinese thinkers. They are unable to understand what the De really is and why only thanks to it also the life on Earth can exists! For them it is now also, like for Confucians, only the moral Virtue!

3 Laozi, Daodejing, its $5^{\text {th }}$ Chapter (translation from Chinese text by author of this paper)
Multiverse).

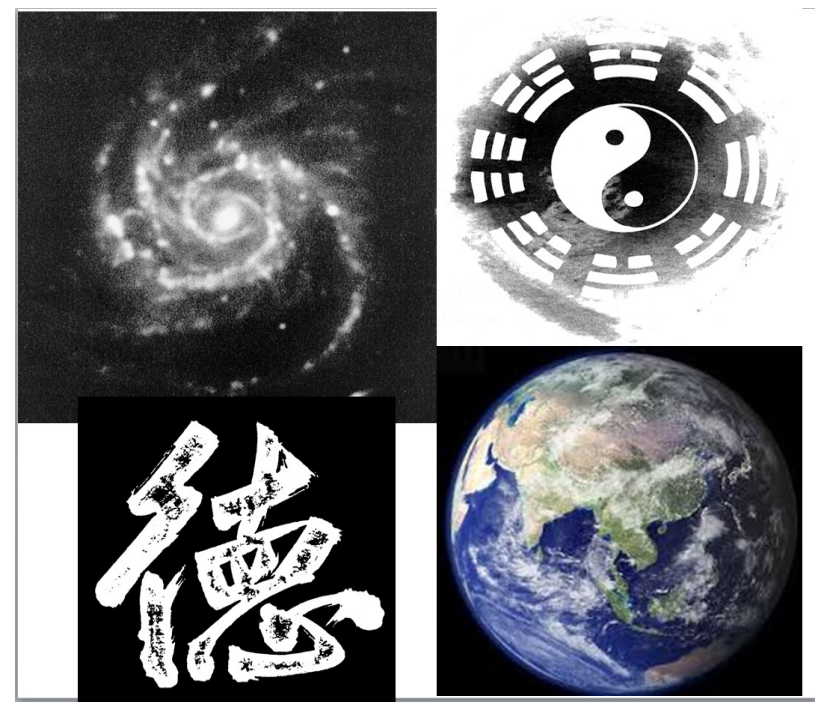

Configuration No. 1. Chinese ideographical character "De" together with a prehistoric graphical image of yin-yang dialectics of being does express the same pure Energy that looks in cosmic photos as the darkness of the cosmic vacuum, or in its vivid form as the life on our Earth:

Heavens 天 (how Laozi used to call Cosmos and the common universe of being) is in accordance with his opinion an endlessly immanent One, eternally creating and changing itself thanks to its Energy $D e$ 德 by its yin-yang dialectical Way Dao 道 in the field of its everlastingly antithetical tensions! Thanks to it everything in this One is infinitely moving in a synergistic unity of all its yin-yang processes of metaphysical and physical, spiritual and material forms and beings, (in cosmic and terrestrial time-space also by Its lower kind of energy $q i$ 氣） gradually creating by this way the profusion of masses of raw materials and states of matters, as well as spiritual souls and antimatter entities, material things and physical beings. And all of it ought to be in everlasting changes of endless cycles of mutually self-organized organic co-existence of all these different sorts of being in a synergically united process of creations and extinctions.

In a text of Huang-Lao (discovered in 1973 in a tomb near the village Mawangduei) such a reality of being is described like this:

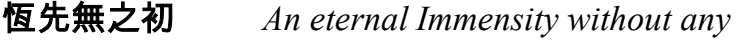

迥同大虛 虛同為一 恆一而止 為其素也

\section{和其用也。}

天地陰陽

四時日月 penetrating through (its) whole Emptiness, and forming at the same time its unity. An endless unity - it's enough!

a perpetual activity is the most characteristic feature of it, and Harmony is its function.

Heaven and Earth, a yin-yang (dialectic), metamorphosis of four seasons, the sun and the moon, 


\begin{tabular}{|c|c|}
\hline 辰雲氣 & $\begin{array}{l}\text { and all the other stars, nebulae and } \\
\text { flows of qi, }\end{array}$ \\
\hline 規行蟯動 & $\begin{array}{l}\text { and all, what is moving and what } \\
\text { crawls, }\end{array}$ \\
\hline $\begin{array}{l}\text { 戴根之徒 } \\
\text { 皆取生 }\end{array}$ & $\begin{array}{l}\text { all, what have roots and what grows, } \\
\text { and all, what again and again is born } \\
\text { and lives. }\end{array}$ \\
\hline 道弗為益少 & $\begin{array}{l}\text { even though the Way (Dao) isn't } \\
\text { thereby reduced }\end{array}$ \\
\hline 道弗為益多 & $\begin{array}{l}\text { even though the Way (Dao) isn't } \\
\text { thereby increased, }\end{array}$ \\
\hline 反焉 & $\begin{array}{l}\text { only everything (in it) is perpetually } \\
\text { upturned into an opposite, }\end{array}$ \\
\hline 玧而 & $\begin{array}{l}\text { while Way (Dao) is (in all its processes) } \\
\text { still indestructible, }\end{array}$ \\
\hline $\begin{array}{l}\text { 下能至 } \\
\text { 下能過 }\end{array}$ & $\begin{array}{l}\text { resiliently flexible and immutable, } \\
\text { so subtle that is not observed, } \\
\text { and so expansive, that is unrivaled...4 }\end{array}$ \\
\hline
\end{tabular}

All sorts of life on Earth, (in Chinese term "ten thousands things"), in accordance with this interpretation, ought to be in an endlessly creative process of yin-yang dialectical transformations thanks to the wisdom and the absolute number of information encoded de facto in the basic nature of the substantial Energy (De), penetrating the whole immanency of Universe, as well as in this time-space's active also Its sub-section, called qi 氣 energy.

In human World it ought to be embodied into Heavens + Earth + Mankind's perfect cooperation in all processes and changes of their highly coordinated Way (Dao). However, in its core is a yin-yangly dynamic antinomian character of processes of being where everything is being done in accordance with its universal inner laws, and thus without any subjective or selfish decisions which would be disassociated from the information encoded into it through the universal Energy (De). Only this Energy anonymously organizes all the processes by its non-subjective wisdom, present everywhere and needed for everything.

\section{Laozi's Specific Ontological Description of this Basic Substance of Being and the Ethical System Arising from it for Humans}

From the ontological point of view it was most concretely described by the ingenious metaphysician Laozi in his lecture, recorded by his disciple Wenzi at the beginning of the $5^{\text {th }}$ century $\mathrm{BC}$, which we know in present time as The Book Wenzi. There Laozi says:

$\begin{array}{ll}\text { 有物混成 } & \text { It existed as a mix-up miscellany } \\ \text { 先天地生 } & \text { yet before the Heaven and Earth, } \\ \text { 惟象無形 } & \begin{array}{l}\text { only in ideas of things without any } \\ \text { forms }\end{array}\end{array}$

4 In author of this paper's translation from Chinese original of the $4^{\text {th }}$ book of Huang-Lao si jing, ed. by Chang L. S. and Yu Feng (1998), published in her monograph, titled "Laozi and the Process of the Genesis of Daode Jing (in Slovak), $2^{\text {nd }}$ Vol., Bratislava Veda Publishers 2012, p. 258-9.

\section{窈窈冥冥}

吾強為之名

字之曰道 5 as an endlessly substantial Darkness

and if I am forced to name it, thus I call it by the mark: The Way

(Dao)!

Though at a first glance these words uphold the Way (Dao) of an universal Energy (De) as something existing before the Universe of being, and thus as a transcendent One able to act as a supernatural Subject, in this book as well as in another texts recording Laozi's thoughts we learn that the Way (Dao) of its universal Energy (De) is not any transcendent entity which would exist before an immanent and everlasting being! Thus as such it is unable to act arbitrarily, and in contradiction with information encoded into the organic laws of being or in opposition to the tension of wise organic unity of the whole complex of processes of every concrete life reality.

In the above lecture, recorded by his disciple Wenzi, Laozi explained this vivid substance of the universal reality of the world also by these words:

無為為之而合乎生死 Without doing anything, everything is done, granting the destiny of births and dying,

無為言之而通乎德 without (any explanation) of it by words everything is flowing then back into the pure Energy (De),

恬愉無矜而得乎和 in a settlement of satisfaction receiving its harmony and quietness without any regret,

有萬不 同而便乎生 in ten thousands of quite another multiplicities transforming (and remodeling at once) again and again into the life

和陰陽 $\ldots$ in the mutual dialectics of yin-yang contradictions....6

As we can see, in accordance with this explanation it is an everlastingly existing amount of Energy transforming from itself (thanks to the required information, knowledge and rules encoded in it) into another-and-another huge amounts of masses of variable formations. All this is only on a base of that yin-yang dialectical Energy (De), organically lasting as an infinite Oneness, in which there are forming, creating and circulating all the different eventualities of ultra-various organic and inorganic entities as well as visible and intangible, spiritual and physical things and matters of the Cosmos's space-time during their onsets, durations, and later also extinctions in their natural terminations, for example also in our particular earthly space-time (according to Chinese philosophical terms called: an "Under-Heaven").

However, this basic Energy of Universe (or Multiverse) isn't always compassioned, as Laozi noticed in his research, and sometimes "Heaven and Earth treat the ten thousand things (thus, also people) inhumanely like the straw dogs 7

5 A similar sentence we can find also in the $25^{\text {th }}$ Chapter of Dao De Jing. 6 See in the $1^{\text {st }}$ Chapter: Dao Yuan 道原 of the Book Wenzi.

7 See Laozi: Daodejing, the 5th Chapter (translated from Chinese by author 
天地 不仁以萬物為媰狗”. So it is only by everyone's choice what position in that yin-yang polarization of its processes one will occupy and to where he will be tending: to the positive or to negative stream of it? From our point of view it could explain to us, for example, why in human history there can appear from the moral point of view such different personalities as was Hitler and Stalin and on the other side Jesus from Nazaret or Francis from Assissi, (or in China the very cruel imperator Qin Shi Huandi and on the other side Confucius).

And what could be very inspiring for modern Humans from such a highly originally conceptual worldview? In our earthly world the whole oneness ought to be embodied in a coexisting cooperation of Heavens + Earth + Humankind's cycles of being realized in their perfectly cooperative synergy. Whole Cosmos with its worlds everlastingly springs from that pure Energy 德 (De)-Darkness-Emptiness, full of its yin-yang dialectical dynamics of movement. However, it is a dynamic, which is like a slave of itself, running in its creations in a hub of organic synchrony (or in other way around devastating discharges) of mutual dialectical interaction of events, and therefore nothing there can be done miraculously or arbitrarily. Contrary to Aristotle's "First Mover" or Judeo-Christian's "God-Yahweh" (or Islamic "Allah") this universal Energy (De) in its everlastingly changing dynamic-dialectical processes of its Way (Dao) has no ability to act helter-skelter, or miraculously and at once subjectively to change something inside the real processes of life and thus arbitrarily tamper with its procedures! Everything, what is created and realized inside it, as it seems, is always according to the whole complex of its internal causes and openings, organized by an internal way of logic within the total process of implications of natural reality resulting from the developments in one's particular space-time as one part of a cooperative body of the complementarity of its being.

So what is, from this Laozi's (as well as the primeval Chinese) ontological concepts implied for the ethical pattern and moral behaviors of a perfect human being? Above all an axiom that a real Man (Sheng ren 圣人), as he was defined by Laozi and the whole ancient Chinese philosophy, needs to act in harmonious cooperation with Heaven and Earth as a truly proper representative of Humankind in this yin-yangly collaborating reality of changes. Therefore, from this ancient Chinese wisdom could emerge a basic ethical imperative that is inevitable for the secure existence of people on Earth. It was expressed already in the $5^{\text {th }}$ century BC by Laozi's main enthusiastic listener, Confucius, in his following ethical predication: "What I don't want the others to do to me, I don't do to others!" 8 Such approach ought to ensure, of course, the best cooperation and collaboration of all individuals in the overall social organism of the World. And to do only that what is in common agreement with the correct

of this paper). Straw dogs were in ancient China puppets of dogs made from straw and used at some folk ceremonies. After the rites they were burned and destroyed.

8 As we see, it is not an ethical commandment for doing "goodness" but a recommendation to decide in every actual situation how to do actively right. social reality of life in its natural world environment one should manage by his internal and in every human nature embedded moral principles, salient from the essence of the human form of being created in the living organism of Earth from the basic Energy (De 德), in Confucius's interpretation from this greatest Virtue.

All these ethical principles in accordance with Taoist and well as Confucian ethical philosophy are:

1) a virtue of filial and fraternal duty (孝 xiao);

2) the rules of rites of mutual human respect (礼 li);

3) a principle of humanity in perfect interpersonal interactions (仁 ren);

4) a principle of acting within the limits of rightness and correctness (义 yi);

5) a principle of loyalty and trustworthiness (信 xin, 忠 zhong).

The basic seeds of these ethical principles are in every person's heart from his/her birth9, but in subsequent social coexistence with people everybody is due to improve himself in their practical applications in communication with people, thanks to developing his/her wisdom (知 zhi) as well as his/her sense for harmonious interpersonal coordination (和 he) of himself with other people as well as with the laws of Heavens and Earth. In every decision one needs to rely on knowledge learned from his teachers or through paternal and societal upbringing, gained in his/her own family as well as in the proper human community. Everyone in the world has his crucial non-exchangeable purpose in the vivid organism of life and no one (in accordance with these ancient Chinese ethical concepts) should allow himself to replace his particular function in life of the world by a selfish or for the common life dangerous practices. Well, if he (or his community) stops to fulfill such objective function in life as it ought to be fulfilled properly in the reality of World, the overall dynamics of life's processes (sometimes embodied into other men) are able to eliminate his chance for a good fate and plunge him into suffering of a human misery. Therefore, everybody is forced to be in his whole life properly functional in the common ongoing processes of life reality and never to stop in it. Because we are the only living particles of the present reality in the vivid organism of World that are able rationally to decide for ourselves what we really will do in the multitude of various processes of their concrete reality.

\section{Modern Western Metaphysical Research and the Similarities Found in its Confrontation with Laozi's Ontological Truths}

In comparison with ancient Chinese, especially Taoist and Laozi's guidance for human life growing from the active 9 But Confucian ethics ignored here the fact that if every man is at once a
yin-yang being and if he has from his birth in his heart the seeds of ethical
principles, so there has also their opposites, and, therefore, not everybody in his life will be able to act only ethically but also unethically. 
duty of the Man to be a perfect vivid reincarnation of the best universal Energy (De) in his/her every specific act of the common Way (Dao) of life, we on the contrary like to believe that everything in our space-time was created by God and that He determinates everything, and thus the best for people is to pray to him and to fulfill His Commandments! At the same time this "apocalyptic truth" evolved (thanks our Western philosophy) into a Weltanschauung in which the yin-yang dialectical antithesis are perceived as rigid and non-exchangeable qualities of "good" and on the other axiological side of the "bad". Thanks to it, people began (thanks to this distorted worldview) to sense the yin-yang dialectic as a fight of "goodness" versus "evil", hoping that the outcome will be a total victory of "goodness" (yang), resulting in our life in a permanent state of a social "goodness"! It is, of course, in real life an absolute nonsense!

Similarly, in Western philosophy since the Parmenides-Plato-Aristotelian times all the "metaphysical" portions of reality were displaced and repositioned into the realms of a "transcendental mystery" of its "First Mover" who existed in eternity even before the real Universe of being began to exist. Therefore, also the reality of being had been frozen by this worldview into rigidly lasting states, which contrary to its real natural circulation of yin-yangly dynamic and synergic-cyclical movements (in accordance with this worldview) ought to be forever only a solid objective being created by a transcendental Subject (God-Creator)! The space-time's being was in Western science and philosophy de facto separated from its real metaphysical components which changed into a never to be known transcendence and entered into the borders of something that is impossible to be researched. Of course, in these Western opinions the metaphysical reality and the physical one (as well as spiritual and material existences) are considered as two separate entities, which are unable to exist together, one with the other.

However, modern science has at the present time even greater ambitions (especially in quantum theory, accelerator physics and astrophysics) to search still deeper and deeper into the basic substance of being, though their agnostic positivism (caused by the above Western Weltanschauung) makes it impossible to understand the real antithetical unity of both different substantive characters of being. Modern scientists can hardly understand the Taoist philosophical truth that reality is an inevitable unity of yin-yangly fluent coexistence and transformations of metaphysical and physical, spiritual and material kinds of being in from itself coordinated unity of an endlessly variable Universe as a Sole, in which also that intangible reality cannot be ignored by scholarly research. Modern physicists in their scientific experiments have already exceeded the limit between matter and anti-matter, and thus also empirical boundaries of space-time parameters of being, but they stubbornly continue believing that it is still within the boundaries of only physics. E.g., in current quantum physics' and astrophysics' experiments many of these scientists research the reality of a "vacuum energy" that has no material parameters and can be really called by the Chinese metaphysical term: Emptiness of Emptiness (or the Greatest Emptiness)大虛” 10, as in its substantial purity it is already truly beyond any space-time material parameters! Thus it belongs already into the realm of metaphysics, as a pure Energy (De) with its yin-yang tensions of dialectic synergy of antithetic and dynamically never stopping process (Dao) of being, as are for example photons, or "strings", or so-called Dark Energy in Cosmos.

One of the best examples of such wrong approach of modern physicists to this dynamic and non-material metaphysical substance of being was confirmed recently in Switzerland by the team of accelerator physicists realizing the CERN's experiment ALICE, simulating "a Little Bang”. Its technological leader, Prof. Karel Šafařík, in his interview The Higgs Boson Isn't Any Divine Particle clearly demonstrated that though he is a supremely capable physicist, who is able to initiate in the CERN laboratories "a collision of heavy ions of the lead (Plumbum), in which its vacuum is heated to a temperature of a million of millions degrees of Kelvin", unfortunately he is not also a good philosopher who should have an ability of the right ontological reflection of these already highly metaphysical findings. When he is using in his defining of the "void" of vacuum the term "substance", he has ignored in it its primary meaning of a fundamental "energy-essence of being" (which is not from the ontological point of view any material "mass"11!). For that reason he degraded this really metaphysical substance of the Universe into a consequential form of the material mass! Consequently, all these dynamic particles present in vacuum, even though they have absolutely zero mass, become in his interpretation "material" ones. So, though he concedes that most of physicists declare that the elementary particle which during the collision of heavy ions of lead $(\mathrm{Pb})$ for a fraction of a second measurably manifest itself and become evident or from its vacuum energy for a split of a second in that abnormally great speed (in the conditions of such high temperature) measurably "materializes" itself, for him is the Higgs boson still within the bounds of "substance" and

10 In Laozi's original texts It is expressed by Chinese ideograms 大虛 (da xu) (a Great Emptiness). The other two ideograms for emptiness (or nothingness): 空 (kong) and 無 (wu) express in Chinese a lexical signification of "nothingness" or "empty" too, but not in such basic ontological sense as 大虛 (da xu). They express "nothing" or "empty" only in a three-dimensional time-space of being on our Earth, but absolutely not such a sense for the basic substance of the everlasting and endless Universe (or Multiverse). 無 (wu) is the "non-being" or an absolute negative in classical Chinese language only as an opposite to the "being" 有 (you) in our time-space reality. You can read, e.g., the definition of Emptiness expressed by 大虛 (da xu) ideograms also in Pregadio's The Encyclopedia of Taoism, 1. Vol. p. 220 (New York, 2008) in accordance with explanation of Laozi's ontology, expressed in Yan Zun's copy of Laozi's De ting: "First comes the Dao, the Emptiness of Emptiness 大虛, followed by its De, which is equated with One and with Emptiness. In turn De comes before "non-being 無" and "being 有", etc..." Also Laozi in his Dao De jing uses the ideogram “ 無” only as an opposite of "being" in the everyday's time-space (see for example the $11^{\text {th }}$ chapter of Dao De jing) or as a negative in the term "non-overreached a marginal extremity 無極 (wu ji)", but never for an expression of the basic ontological Emptiness of a universal being. The same goes with using the ideogram 空 (kong). It is only a lexical term for time-space's emptiness (for example inside a house), but not for the metaphysical or philosophical terminology for the real cosmic or universal Emptiness!

11 Energy isn't (as I learned from Laozi's philosophy) only an attribute of the material mass but contrariwise every material mass is only a form of energy in the state of its relative tranquillization. So, initial and basic is the universal Energy and material mass is in it a secondary phenomenon. 
therefore, in his agnostic-materialistic understanding of this term still within the status of a mass. Furthermore, thanks to this philosophically misconceived interpretation of "substance" of universal being, for him is also "gluon field" in which is hidden $90 \%$ of the pure energy, only a material matter! After reading his interview one comes to an impression that even the terms "strings" or "fluidity" and all others which he used to explain these experiments, he understood as a kind of very concrete, although specifically invisible, but really material strings, and so on. He is a physicist who in these experiments (of which is the actor) is penetrating already beyond the boundary of physics into the realm of the non-visible being, but has no philosophical ability to understand this process really metaphysically. On one hand it is very fine that he admits an existence of a whatsoever entity of being before the "big Bang" and thus before the emergence of the space-time's reality of our Cosmos, (what many western professional philosophers are unable to imagine and so, before the "big Bang", they situate only a transcendence in the sense of a monotheistic "God"), but on the other hand, by his misunderstanding of the term "substance" even the "Dark Energy" is for him only the largest portion of a material matter in Cosmos. Every truly critically thinking philosopher ought to be simply shocked by such awry interpretation of the metaphysical substance of Universe (or Multiverse) as well as of its inner part, our Cosmos!

However, thanks to CERN's ALPHA experiment, it had been scientifically confirmed that also in our time-space reality really exists at the same time not only a matter with its "antimatter", but also something, substantively much more pure than space-time's antimatter, presumably the absolutely intangible particles of a pure energy, which even after the "Big Bang" (that created our space-time) did not cease to be from the metaphysical point of view an absolute material nihil, and thus from the material point of view have really an absolute zero of mass.
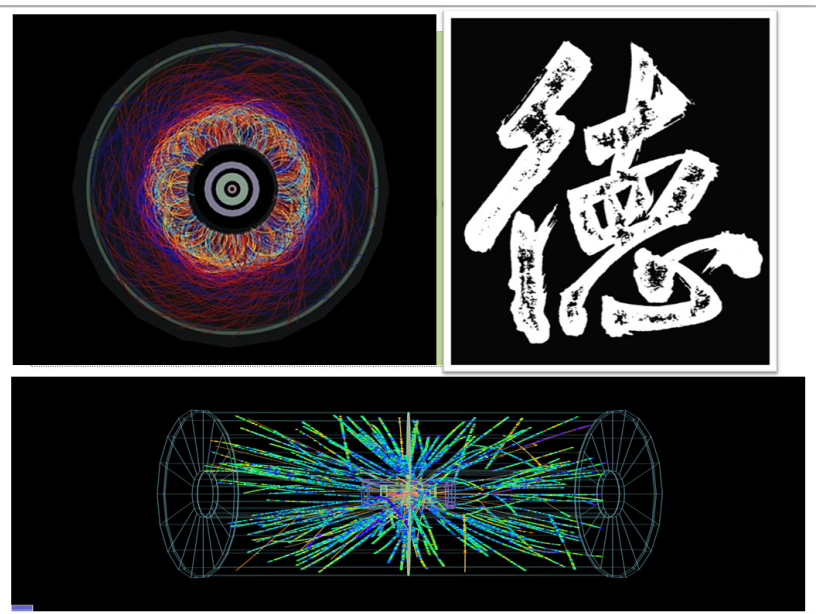

Configuration No. 2. Chinese ideographical character "De" expresses in Laozi's ontology the same pure Energy as is "boson" in CERN's experiment ALICE:

This metaphysical Nothingness is still immanently present in our space-time without there being a "transcendental

being", e. g. a transcendental Subject - a God. Even these latest modern discoveries of natural science confirmed that the so-called "Higgs boson" is (according to the standard model of particles) a particle without any opposite, and thus with really zero charge, what is actually regarded to be from the point of matter an absolute "emptiness"! If it is in its forever dynamic spin " 0 " (really zero!), in such case it is a scalar boson, i.e., essentially in terms of the tangible parameters even "emptier" and more "immaterial" energy of being than what we already know as the "photon". This already pure energy has a totally invisible presence and, as it was confirmed by experiments at CERN, it can be observed only under highly special conditions of space-time, which are achieved, for example, at a high speed collision of the lead ions, when it "twinkles" in the most minimal fraction of time into an empirically observable 'particle'.

All this documents also the fact that "mass" is only a relatively lasting form of the substantial Energy (De) of an eternally endless Universe/Multiverse of being, and each of material forms, including the physically or organically living form of being arise in their origin (through a long process of many changes) from this fundamental Energy (De) which is (according to the classical Taoist and Laozi's view) present always and everywhere in the whole space-time being, therefore, also in our world between "Heavens and Earth" (as the Chinese used to call our world!). According to in itself existing anonymous wisdom (expressed in terms of our modern quantum theory: "because of the presence in it of an absolute amount of information") also in the space-time of our Cosmos everything is there forever "creating, existing and becoming extinct" in such a way without any subjective decision or causation of a transcendent Somebody who would care about it and was able to manage it, but only thanks its inner principle of the natural laws.

This anonymous Energy (De), full of all information which is needed for every change in the existence of being, ought to be, in accordance with this explanation, an everlasting metaphysical substance of the Universe, and thanks to the philosophical work of Old Master (Laozi) it was already at the turn of the $6^{\text {th }}$ and $5^{\text {th }}$ centuries $\mathrm{BC}$ described as follows:

窈穷冥冥

寂胗淡漠

\section{天常之道}

生物而不有

成化 而不宰

万物恃之而生

莫知其德
Still the deepest and endless Darkness, absolutely inaudible and indistinguishable

...... by its generally regular Way (Dao) of Heavens

creates and produces things without any appropriation,

successfully implementing their environmental transformations without being commanded into it (or arbitrarily) determining it, and tens of thousands of things in it are formed and born, without knowing it is thanks to the Energy (De)! 
虛無恬無形大
And the Emptiness (presenting this
Energy) is the most greatly marvelous
because it is an absolute non-being
without any forms! 12

It is surprising, but certainly not coincidental phenomenon that also our modern world cosmology, based on the real space researching technologies, recently points to the similar knowledge! According to its discoveries: "Dark energy is a hypothetical form of energy that pervades all of space and leads to acceleration of its expansion ... In the standard cosmological models the dark energy corresponds currently to $73 \%$ of the universe ... nature of the dark energy is the subject of conjecture. We know that it is very homogeneous ... a dynamic quantities whose energy's density can vary in time and space. Contributions from scalar fields that are constant in space are usually also included in the cosmological constants. The cosmological constant is physically equivalent to vacuum energy.... and this dark energy has been used as a crucial ingredient in a recent attempt to formulate a cyclic model for the Universe..." 13 In comparison with it a similar ontological knowledge in its background was clear to Laozi already 2,500 years ago (without any aid of telescopes or such extremely expensive accelerator experiments as is that one in CERN), but thanks to CERN's modern confirmation it is already scientifically discovered as a very important cosmological axiom about the basic nature of the substance of universal being which surrounding us in our space-time too.

\section{Conclusions}

If the everlasting Universe of being (and thus also in the whole Cosmos, including Earth and the world on it) occurs thanks to its own antithetically bipolar Energy, and the Energy (De) is a medium of an universal wisdom including in itself all necessary information, it is (in the frame of its yin-yang dialectical activity) the only organizer of its whole immanent convertibility! This important truth has been confirmed not only by the ancient Chinese cosmology but just also by the present world accelerator physics! In such case, of course, we cannot live already on Earth in a dream that we are the favorite children of a Protector (God) who would be able to do for us everything what we need, if we'll ask Him in our prayers. In the endlessly dialectically dynamic and yin-yangly changing circulation of being which includes in itself a perfect all-encompassing wisdom of further eventualities for every mutually dependent time-space's changes of their existence, we, as its active inner particle, are really extremely forced by it to do

12 See it in the $1^{\text {st }}$ Chapter Dao yuan of the book Wenzi .(Translated from Chinese by the author of this paper)

13 P.J. E. Peebles and Bharat Ratra (2003): „The cosmological constant and dark energy" Reviews of Modern Physics 75, 559-606 and Seven-Year Wilson Microwave Anisotropy Probe (WQMAP) Observations: Sky Map, Systematic Errors, and Basic Results“(PDF), nasa.gov. everything, what we do, in harmony with this yin-yang dialectical and often very cruel and uncertain environment. Everything here is so originally, regularly, dialectically changeable not only in its material existence but also in its spiritual and immaterial vivid social reality and thus no transcendent Protector can help us or rescue us from a disaster, if we will not take care to keep ourselves in harmony with the whole surrounding us environments of life and not be ready to accept a right decision in every intercurrent act of life. Mainly the Western civilization, and inside it not only Christian, Jewish or Islamic believers who believe in the God-Protector, but also all the atheistic Westerners, whose worldview (in their prehistorical origin) grew from a nomadic existential predilection in making wars of conquests and under their despotic ambitions forcing everybody as well as every country under their rule to live in a conformity only with their Western lifestyle, ought to need very urgently to change their traditional worldview's habits and begin to learn how to live in an optimal respect of authority and sovereignty of habits and worldview of other human cultures in the World, which can be sometimes much more useful for the everyday human life than those we currently profess in the West. If not for other reason than because another World War (because of such highly developed war industry) would totally liquidate Humankind on Earth. Conquerors' outlook on life by one part of Humans against another is in our present times already dispensable. In the age of global citizenship in common World's village, we should already begin to prepare for a contact with other highly developed civilizations in our Cosmos, (as it is implausible that we are the only ones there)!

Our living space on Earth is like a living body of one vivid organism of being and we are as cells in the human body. For a human body to be healthy, all its cells must perfectly fulfill their individual tasks and responsibilities and co-operate in harmony. Thus everyone in the world (as well as all countries) is forced to perform his/her life's tasks in harmony and co-ordination with all surrounding environments. All nations in the world are the people whose living function is to represent Humankind of Earth, and become a compact vivid organism of people with their new purpose. Laozi in the $12^{\text {th }}$ chapter of Dao De jing said:

\section{是以聖人 Thus the real Man (by his whole human activity)} 為腹不為目 realizes everything for means of living (of Humankind) and not for eyes (thus not for the outside effect),

\section{去彼而取此} and so rejects that and obeys this one!14

And "this one" ought to include also a perfect and rational cooperation in the modern scientific research, which needs to cease to do scholarly experiments in separation from other fields of the progressive human knowledge. Thus many different fields of science have to

14 Laozi: Daode jing, the closing part of its $12^{\text {th }}$ Chapter (transl. from Chinese by author of this paper). 
interface into a common organism of human research in perfect cooperation of many various disciplines of our scientific efforts (even if some scientists would thus get into a contrariety with their traditional worldview or confessional convictions).

\section{GENERAL NOTES FOR BETTER UNDERSTANDING OF MY ARTICLE:}

1) In accordance with Laozi's and ancient Chinese bipolarly yin-yang dialectical ontological interpretation of being, the "metaphysical being" is not any fixed separate part of the Universe/ Multiverse, or some transcendent entity that existed yet before the Universe would have started to be. It is always only one of the antithetical components of being inside the Universe/Multiverse, in which it (as well as other parts of its reality) is creating itself from the essential substrate of a universal being, a pure Energy (De) - (in our modern term: "boson"). This substantive energy of being is perhaps eternally existing inside the whole Unity of being, within the frame of its bipolarly dialectical basic charge particles which never could be a singular set, but thanks to which everything is forever creating, existing and annihilating all the multitude of processes and forms of the material world also in our cosmic space-time being. These processes and their forms, structures and contents are (supposedly) in their cyclic dialectics metaphysical as well as physical, spiritual and material, organic and inorganic entities, which are naturally and mutually creating and annihilating in their relatively different cases of their never ending dialectical transformations. These processes, however, are never really linear but in fact they are dialectically (yin-yang) reversaing and circulating and in our time-space, where we can empirically observe and research them, are multi - dialectical. Such ancient Chinese ontological interpretation of the "universal Unity" is in strong opposition with the monotheistic vision of Cosmos, created by a God-Creator. No mass and its material existence there could be causally created by a transcendental Subject, and both: "metaphysics as well as "physics", spiritual and material entities are dependent for their existence and life span on the just-occurring basic dynamic contradictions and their inherent regularities inside the specific processes of their changes. All knowledge (needed for these creations, their lifetimes and annihilations) is inside the elementary particles of its everlasting Substrate - the pure Energy (De), which is always and everywhere throughout all entities of the space-time existence of our Cosmos inside the Universe (or Multiverse) of being. From the empirical point of view, this basic energy (De) of the universal being is "Nothingness" or "Emptiness", thus something what is only a pure movement and of course, not an autonomously thinking Subject. It is quite anonymous but throughout itself a highly organized, bipolar, dialectical, dynamic flowing from which absolutely everything of our reality is emanating. In relation to its immanency, nothing and nobody was there before it and thus no transcendental being before it ever existed! Our Cosmos, and thus our time-space began to exist inside this infiniteness of Energy (De) thanks to the Big-bang, but the infinite and everlasting Universe (or Multiverse) of being was and will be still before and after our time-space in many different forms of the phenomenal entities of the process of changes (Dao) from its forever dynamic substrate $-\mathrm{a}$ pure Energy (De).

2) Under the term "physical" we should not understand that it encompasses all what we can examine by the "physical means"! In case that the reality of being is simultaneously constituted by mutual dialectical contradictions, and thus by material and immaterial, substantial and unsubstantial, physical and metaphysical forms of being, all that ought to be, of course, perceivable by some highly advanced technical means. (And not only "material" or "physical" things but also those that are empirically "intangible"!) Therefore, also the "intangible entities" can be examined by such material (physical or technical) means (as was e.g.: Laozi's judgment, formed in his cerebral gray cortex; or as are the modern technical gadgets thanks to which modern physicists are able to detect the frequencies of photons or by the ALICE accelerator at CERN to develop even such extreme conditions in which a metaphysical "boson" (or in Laozi's term "De" or a "Nothingness") at a fraction of time will "flesh out" into a twinkle. However, from that "boson" or Laozi's "De" or "Nothingness" (de facto the pure primary energy of being) also all natural processes in our world continuously create and form as well as destroy and annihilate (thanks to its dialectical movements containing all for it necessary information) all things and activities in its time-space reality! Hence, why could it not be possible in experiments such as the Swiss accelerator with its brief scintillation to make that basic Energy of being visible, though it is evidently in its basic form far beyond the frame of the material mass?!

3) Photons cannot be in a state of quiescence or stillness, not because they have a zero "mass" but because they are pure energy, and thus they are inherently unable to be at peace and in an absolute singularity. The visible form of a relative "peace" or a quiescence of the basic energy of being is the "material mass" (which, on the contrary, cannot have a zero mass!). Just after creation of any material object there begins freeing and escaping of streams of photons (which determine object's inevitable duration until its 
destruction and condensation into a highly packed mass e.g., our Sun changing at last into a maximally hard dwarf, which at least will finish in Black Holes). Therefore, every particular matter will sooner or later cease to exist in its previous form and shrinks into a white or dark dwarf equivalents, because all its "massless particles" (i.e. energy) "evaporate" from it. The massless particles are not "massless" (or nonmaterial) because they are intangible, but because they have their "dynamics" thanks to the fact that they are the pure energy and absolutely no "matter"! Without their dialectical dynamics they would not be able to exist because the yin-yang (dialectical) dynamics is the only detectable characteristic of this pure energy (the basic substrate of being), designated by Laozi as De (or as Nothingness or Emptiness or Darkness). In fact, they are a pure (dialectically creating) movement forming inside its own bipolar-dialectic (yin-yang) counterparts.

4) Classical mechanics works only with material objects, and therefore they cannot imagine energy without a matter! But it is interesting that in the current particle physics the weight of elementary particles was supplanted from a measure of weight to a measure of energy (in electron Volts)!

5) "Time" and "space" are only auxiliary terms applicable to our Cosmos' space reality, which then becomes better understandable. The reality expressed by this cosmic time-space is only one of the just phenomenal forms of being of the pure energy of being, which as such is the basic substrate of the whole everlasting and never ending Universe/Multiverse. Therefore, also our Cosmos is full of this omnipresent emanating Energy (thus also we on Earth are in it "as a fish in the water"). It is everywhere, and thus that what our scientists perceive as a "vacuum" and, therefore, like a void of material mass, is not a real "emptiness" at all, but a metaphysical dynamics of the pure energy without any material form in that time-space. In vacuum, as physicists have found out, there are flowing "elementary particles" with their positive as well as negative charge, so de facto it is not empty but full of everlastingly flowing energy! The rationally thinking physicists have divided the "elementary particles" into "particles" and "antiparticles" (thanks to their antithetical charge), though all of them are the essential elements of the same yin-yang bipolar dialectical Energy of being! Thanks to its antithetic charges it shows that it is in its basic existence really a synergic-emerging-movement of pure energy. Such energy cannot exist in a state of only a "positive" or a "negative" charge, though has inside itself particles with "positive" or "negative" antithetic charge!
P. S.

(I spent already more than 20 years on an extensive comparative scholarly research and translations of all existing copies of Laozi's philosophical work. Such research and comparative translations were not yet made not only by any Western Sinologist, but also by any Chinese Sinologist up to the present time (see my 2-volumes monograph Laozi and the genesis of Dao De jing by Marina Čarnogurská, Veda Publishers, Bratislava 2009 and 2012). For that reason all my conclusions, presented in this paper are not a speculation but the result of my very long sinologic research. It is, of course, in an absolute contrary with the traditional explanations of Laozi's philosophy as well as the ancient Chinese worldview made in the past by Western Sinologists, maybe because they read and translated these Chinese texts mainly in their linguistic sense, using for it only our European ontological or scientific terminology, and not in its real ancient Chinese ontological expressions. For that reason all these my discoveries are from many points of view quite untraditional and the newest in modern world sinology.)

\section{REFERENCES}

in Chinese:

[1] Laozi jicheng (A Collection of Editions and Commentaries for the Laozi). 15 volumes, Zongiiao wenhua chubanshi, Beijing 2011

[2] Dao yuan“ in Chuan-Lao si jing, ed. by Chang L. S. and Yu Feng (1998); or by Chen Guying (1995); as well as in Chen Yaoting's edition from Shanghai Academy of Social Sciences or The Taoist canon under the title: Zangwai daoshu, compiled by Hu Daojing. Bian zhu (a collective of compilers) in: Mawangdui han mubo shu, Wenwu chuban shi, Beijing 1980.

[3] HESHANG kung: Dao De jing in Tao Te Ching, Zongjiao wenhua chuban shi, Beijing 2007.

[4] HESHANG kung: Dao De jing in ZHANG, Yunliang: Song Mashaben Laozi Dao De jing, Gugong bo wu yuan, Shanghai 1932 (reprint 1991).

[5] LAOZI zong mu he Wang Pi zhu, in the book LAOZI, ZHUANGZI, No.9213 of Ssu-pu pei-yao, Chung-hua shu chü, Taipei 1965 (reprint).

[6] WEI, Qipeng (ed.): Mawangdui han mubo shu „Huangdi shu“jianzheng, Zhonghua shuju, Beijing 2004.

[7] WENZI: Wenzi zuanyi,in No. 9221 of Ssu-pu pei-yao, Chung-hua shu chü, Taipei 1965 (reprint).

In European languages:

[8] Fyzika častic Wikipédia.sk.wikipedia.org/wiki/Fyzika_častíc (in Slovak)

[9] Higgsov bozón - Wikipédia, sk.wikipedia.org/wiki/Higgsov_bozón (in Slovak)

[10] ČARNOGURSKA, M.: Laozi and the Process of Genesis of 
Dao De jing, 2. Vol, (in Slovak) Bratislava: Veda Publishers, ISBN 978-80-224-1274-2

[11] CONFUCIUS: Lunyu (In Slovak translation of Marina Čarnogurska Rozhovory a výroky), Bratislava: Slovenský Tatran, ISBN 80-222-0529-X

[12] PEEBLES, P. J. E and BHARAT, R.: The cosmological constant and dark energy. In: Revies of Modern Physics, Vol. 75, pp. 559-606.

[13] PREGADIO, F. (ed.): The Encyclopedia of Taoism, 1. Vol., p.
220, Routledge, Taylor \&Francis Group, London and New York, 2008.

[14] STAVRIANOS, L. S.: The World to 1500, A global History. Englewood Cliffs, N. J.: Prentice-Hall, 1970, ISBN 13-968123-X

[15] ŠAFǍ̌ÍK, K. (2013): The Higgs boson isn'a any divine particle. An Interview in Slovak In: http://spravy.pravda.sk/domace/clanok/280172-higgsov-boz on-nie-j.... 